Journal of Jungian Scholarly Studies

Vol. 1, No. 1, 2005

\title{
Archetypal Literary Theory in the Postmodern Era
}

Darrell Dobson

\section{Introduction}

The place of archetypal theory in the academy seems always, or at least regularly, to have been uncomfortable; however, one of its most robust and academically successful advocates has been Northrop Frye, who in Anatomy of Criticism delineates an archetypal approach to literary analysis. A biographer declares Frye to be one of the most cited authors of the twentieth century, behind only Roland Barthes, Lenin and Freud, and credits him with publishing three of the most influential books of literary criticism of all time: Fearful Symmetry, his study of Blake, Anatomy of Criticism, and The Great Code, in which Frye applies archetypal literary theory to The Bible (Ayre). (Ayre published before its companion piece, Words with Power (1990), was released.)

Archetypal literary theory begins, however, with Carl Jung, and he most clearly addresses the topic in The Spirit in Man, Art and Literature, which contains two essays (first published 1922 and 1930) about literary archetypal analysis and one discussion of James Joyce's Ulysses. As early as 1912 in Psychology of the Unconscious, Jung analyzes Longfellow's Hiawatha, though he never wrote a full psychological analysis of a literary work (van Meurs 19). Jung's theory and practice require constant amplification of archetypal themes as found in literature, and favored and much cited works include Dante's The Divine Comedy, Goethe's Faust, and Nietzsche's Thus Spoke Zarathustra. Influenced by Jung, many others have implemented archetypal theory in literary studies. For instance, Jos van Meurs' bibliographic survey of Jungian literary criticism between the years 1920 and 1980 runs to nine hundred entries.

However, due to the influx of critical postmodern perspectives throughout the last two decades of the twentieth century, archetypal criticism generally, and Frye's influence and prestige specifically, began to wane. Frye clearly does not implement a Jungian archetypal analysis; however, while within the field of archetypal literary theory scholars may distinguish between Jungian archetypal theory and other types of mythological or archetypal theory, outside of this field such fine distinctions are often conflated by its critics. 
Frye's work was and is criticized as hopelessly modernist, and Frye was unable or uninterested in answering his postmodern critics in a manner they found compelling. I hope to demonstrate that archetypal theory, as articulated by Northrop Frye and Carl Jung, remains a powerful tool in literary criticism. I find much that is compelling in both postmodern and archetypal theory, and I hope to use archetypal literary theory to posit a solution to a postmodern critique regarding the role of ideology in literary analysis. I propose that the means of doing so has suggestive implications for answering critiques of archetypal theory throughout the academy.

Northrop Frye's emphasis on the universal nature of mythic structures and the resulting privileged position he accords to mythology over ideology, is problematic for many scholars, including Deanne Bogdan, who criticizes Northrop Frye from a postmodern, feminist perspective. I will first present Frye's and then Bogdan's positions regarding the relationship between mythology and ideology, and then I will explicate some relevant aspects of Jungian archetypal theory not considered by either Frye or Bogdan. In the end, I will attempt to synthesize the theoretical positions of Frye, Bogdan and Jung in order to posit that Jung provides a means of explaining archetypal literary theory to its critics without dismissing their valid concerns. I hypothesize that this synthesis will contribute to positioning archetypal theory in such a manner as to allow it to remain cogent and relevant in light of postmodern critiques, and to do so without marginalizing or ignoring postmodern theoretical insights.

\section{Northrop Frye and Ideology}

In Anatomy of Criticism, Frye defines the aims of archetypal literary theory as an attempt to describe a few of the basic grammatical elements of literary expression in the classical and Christian heritage of the western literary tradition by focusing on the aspects of literature that are comparable to tonality, rhythm, and canonical imitation in music (133). In "Forming Fours," a review of Jung's Two Essays on Analytical Psychology and Psychology and Alchemy, Frye describes archetypal literary theory as "that mode of criticism which treats the poem not as an imitation of nature but as an imitation of other poems. It studies conventions and genres, and the kind of recurrent imagery which connects one poem with another" (616).

By mythology, Frye means the underlying structure discernible in stories. About mythology, Frye points out there are only a few species of myth though there are an infinite number of individual myths (Words with Power 23). For example, these species, or archetypes, of myths include "myths of creation, of fall, of exodus and migration, of the destruction of the human race in the past (deluge myths) or the future (apocalyptic myths), and of redemption" (23). Frye uses the term archetype differently than Jung does. By archetype, Frye means only a 


\section{Dobson}

recurring pattern. In Anatomy of Criticism, he clearly states that he sees no need for the collective unconscious in the domain of literary studies (112).

By ideology, Frye means "structures of social authority" (WP 16), wherein "the principle invoked is that we belong to something before we are anything, that our loyalties and sense of solidarity are prior to intelligence. This sense of solidarity is not simply emotional, any more than it is simply intellectual; it might better be called existential" (18). Frye identifies ideology with solidified dogma (22). He thinks that "an ideology starts by providing its own version of whatever in its traditional mythology it considers relevant, and uses this version to form and enforce a social contract. An ideology is thus an applied mythology, and its adaptations of myths are ones that, when we are inside an ideological structure, we must believe, or say we believe" (23). Frye asserts that an ideology's desire to make its own canon and perspective the only acceptable choice results in intolerance and persecution as all other perspectives are denounced as heretical or perhaps even evil (24).

Frye gives priority to mythology over ideology because ideologies develop and dissipate while the archetypal myth remains. Mythologies, or archetypal patterns, are capable of being created and viewed through many ideologies. Myth is a source of ideology (WP 31) but is not dependent on ideology. Ideology is a partial and static implementation of the fluid myth or archetype. In the following excerpt, Frye makes his point about the value of mythic structure over ideology:

The principle involved is that there is a flexibility in the story that its ideological reference does not permit. To paraphrase an axiom of D.H. Lawrence, we should trust no writer's beliefs or attitudes, but concentrate on his [sic] myth, which is infinitely wiser than he is, and is the only element that can survive when the ideology attached to it fades (60).

It is this very flexibility of the archetypal structure that in Frye's mind gives it more value and privilege than ideology, which is less likely to be flexible (24).

For Frye, the ideological is also less valuable in literary theory because it places a political or personal agenda before a literary agenda. Frye characterizes many contemporary critics as still being stuck in what he terms an ideological stage because they are interested in their ideology more than they are interested in literature; they approach literature first from a feminist, historical, radical, postcolonial or religious position (WP 27). Frye anticipates ideological criticisms of his theories, and of literature, and he presents such an ideological emphasis as a hedge clipper, trimming away - denying the value of - all that does not fit the ideology. The hedge (literature, myth, archetypal structure) is made to fit the view approved by the ideology (WP 60). 
In Words with Power, Frye does not seek to deny ideological approaches to literature; he accepts them as valid and valuable. He says only that should be some critics who are interested in literature before ideology and that they should deal with literature in terms of its own metaphorical and mythical structures and language (WP 27). Frye explains the relationship between mythology and ideology as follows: "I think of a poet, in relation to his [sic] society, as being at the center of a cross like a plus sign. The horizontal bar forms the social and ideological conditioning that made him intelligible to his contemporaries, and in fact to himself. The vertical bar is the mythological line of descent from previous poets back to Homer" (47).

Frye's success in gaining acceptance for the separation of mythology from ideology has only been partial as the arguments Frye has asserted about the dead end of ideology have not been widely accepted (Salusinsky 82). Frye himself must have been dissatisfied with the success of his project as he spends one hundred pages of Words With Power revising and restating his concepts of ideology and mythology, a discussion he first broached in The Critical Path, twenty years earlier (Salusinsky 78). For reasons I will investigate next, Deanne Bogdan, for one, remains unconvinced by Frye's conception.

\section{A Postmodern Critique}

Bogdan sifts through Frye's theories carefully, scrutinizing them to see what she can accept and what, in consideration of current feminist research, must be submitted for re-education. In the final chapter of her book Re-educating the Imagination, (the title a comment on Frye's The Educated Imagination) she considers the hierarchy of mythology and ideology. Part of Bogdan's concern with Frye's hierarchy is that it while it claims to be without ideology, it actually invokes a patriarchal world view (274). Bogdan also asserts that one's situatedness determines what one notices and does not notice, and that if one emphasizes myth over ideology, it makes it very easy for one to accept, or not to notice, or to place little value on aspects of a text (myth) that are unacceptable to the ideology. According to Bogdan, asserting the hierarchy of mythology over ideology makes it more likely that readers and critics might notice but then pass over patriarchal, homophobic, and racist elements of literature (278). In Re-Educating the Imagination, Bogdan responds to Frye's image of the intersection of the vertical mythological line and the horizontal social and ideological line by asserting that her "impulse to remake and redo this text would be to say that for women and women writers the center of the cross is more like a minus sign"(277).

Rather than a hierarchy, Bogdan conceptualizes mythology and ideology as inter-related and permeable. "We might say that the attention constructs influencing what is regarded as fictional and what, real ...become skewed when logos is mistaken for mythos. Part of getting them straight, I submit, involves 


\section{Dobson}

making gender a marker of the permeable boundaries between ideology and mythology" (281).

In Beyond Communication, Bogdan presents a feminist analysis of Canadian author Sinclair Ross's short story, "The Painted Door," in which she points out the story's patriarchal implications (150-154). In Bogdan's ideological interpretation of the story, the sexual agency of a female protagonist is blamed for the death of her husband and results in a burden of guilt for the woman. Tragic events result from opening the Pandora's box of female sexuality. Thus female independence and sexuality are dealt a blow by patriarchy. In this view, the story would be problematic for many readers. I find this aspect of Bogdan's analysis understandable and valid from a feminist point of view, though I would offer an alternative interpretation from a Jungian perspective.

Bogdan also goes on to refer to Robert Scholes' description of the patriarchal nature of narrative itself due to its structure of delayed gratification (186). She cites Teresa de Lauretis, a film theorist, who presents a feminist critique rooted in Freudian psychoanalytic principles. She argues "trenchantly that the thrust toward fulfillment of desire by way of progression from beginning, middle, to a climatic end, wherein the hero's sense of loss is restored by a renewed vision of how things are, is a male paradigm" (186). Bogdan also concludes that narrative form is itself inherently patriarchal (187), a position that I find problematic. Bogdan asserts that this realization dissolves the hierarchical relationship between mythology and ideology because "the genderization of narrative form renders mythology itself ideological" (187). So Bogdan first presents an ideological critique of the story and then secondly goes on to declare that the narrative form itself is patriarchal. The combination of two moves, but especially the second, seems to invalidate other perspectives and to position Frye's desire to separate myth and ideology as an unacceptable patriarchal remnant.

Bogdan is obviously not the only critic of Frye, and feminism not the only postmodern ideological perspective from which to criticize him. I will now briefly introduce two other relevant postmodern critiques of Frye. I do so to illustrate the degree to which Frye has been marginalized and to investigate how Jung's archetypal theories might respond to some valid concerns of postmodernism as well as to Bogdan specifically. In an article entitled "Frye's place in Contemporary Cultural Studies," Hayden White conveys concern from another perspective:

Contemporary practitioners of what has come to be called 'cultural studies' have not on the whole found much of use in Frye's work. In part that is because cultural studies is a neo-Marxist activity...and paranoically hostile to anything smacking of formalism, structuralism, idealism, or organicism. Insofar, then, as 
Frye's work is noted at all by practitioners of cultural studies, it is as an example of these fallacious or misguided (insofar as they are ahistorical) ideologies. He is put down as one who believed that literature was paradigmatic of culture, that culture itself was an autonomous vis a vis society and the modes of material production that determine dominant social formations, and that, accordingly, both culture and society can be studied only in an ahistorical, which is to say, a synchronic, structuralist, or formal manner. The panorama of historical occurrence which Frye is supposed to have confronted consists of a finite set of forms of cultural expression of which literature is a paradigm. These interact significantly only with one another and not at all with the more mundane world of economic, political, and social praxis, and they develop only insofar as they succeed one another in positions of dominance and subordination cyclically (rather than progressively or developmentally or dialectically). For Frye, it would seem, everything happens in cycles. So goes the negative account of Frye's system (29).

Wladimir Krysinski articulates another postmodern critique of archetypal theory in his article, "Frye and the Problems of Modernity." Krysinski critically analyzes Frye's affinities with modernism and structuralism. Krysinski invokes Jean-Francois Lyotard's concern with metanarratives, as an example of structuralism, to make his point: "It is important to bear in mind that Lyotard explicitly links metanarrative and metadiscourse to his definition of the modern...Lyotard defines the postmodern as an 'incredulity toward metanarratives" (256). Certainly the attempt to find the archetypal structural similarities inherent in literature has qualities of a metanarrative or metadiscourse and so will be suspect from a postmodern perspective. Archetypal theory does consider that which might be held in common, might be shared, may even be universal, and these are the very concepts critically analyzed by the postmodern emphasis on the unique, particular and situated (I will show below that Jung provides the balancing emphasis in archetypal theory on the individual and the situated). Postmodernism is defined by its resistance to overarching metanarratives of a kind found in Frye's theories. I posit that the archetypal theory of Carl Jung can be used to assuage some of these concerns and respond in a more compelling manner than Frye can to a postmodern critique.

\section{Archetype and Archetypal Image}

In an attempt to bridge the gap between Frye's modernist archetypal perspective and its postmodern critique, I will now present a further exegesis of an important aspect of Jungian analytical psychology. It is important for my project to consider Jung's differentiation of the 'archetype' from the 'archetypal image.' The archetype is unknowable and irrepresentable; it is merely a shared impulse to create 


\section{Dobson}

pattern; its nature can only be guessed at from an overview of its representations, all of which are located, specific and embodied in dreams, rituals, myths and art. As the 'archetype' is transformed into the 'archetypal image' it takes on the characteristics of the individual and/or collective into which it arrives. Archetypal images are transformed by the psyches that create them in order to provide a balancing message for that psyche; the archetype is transformed into an archetypal image that responds to the needs of the specific ego. If the collective or individual psyche, for instance, is patriarchal, the archetypal image may be influenced by that attitude; it may manifest what is happening in order to encourage consciousness of the situation or it may manifest what needs to happen in order to illuminate possibilities that might achieve balance (Jung, FA 5).

The archetype is not defined by the content of any one manifestation nor even by the accrued total of all its manifestations. Archetypes are apolitical; archetypal images are political; archetypes are not ideological; archetypal images are located within ideologies. (Jung, FA 13; see also Jung, OTNOTP, 123).

The archetypal image can never be known in a pure form; it can only be inferred from the collection of its situated and ideological manifestations. An archetype is not a Platonic form that exists separately from its manifestations: it is the shared aspect of unique manifestations. It is my premise that Frye's assertions that mythology and ideology can be separated were an attempt to distinguish between the archetype and the archetypal image but that he lacked the depth of Jungian archetypal theory to articulate his distinction.

\section{Ideology as Archetypal Image}

Without the nuanced aspect of Jungian thought that distinguishes between archetype and archetypal image, Frye's archetypal literary theory has not been able to respond to its postmodern critics because Frye has not been able to articulate how the apolitical myth or archetype can be considered apart from its political manifestation. Willard defines the problem:

Archetypal criticism, so called, has gone out of fashion during the last decade or two. Partly because post-structuralism has rejected the very possibility of a 'totally intelligible' criticism such as Frye hoped to derive from archetypes, and partly because the old determinisms that he rejected-Marxism, Thomism, and the like (AC, 6, 17) - have been replaced by the new determinisms of race, class, and gender, which resist anything that smacks of elitism. It is commonplace to say, as Charles Baldick does in The Concise 
Oxford Book of Literary Terms, that archetypal criticism is reductive and ignores 'cultural differences' (17). These changes remind me of a remark that Alfred Harbage made in the early fifties, not long after having been selected over Frye for a Shakespeare position at Harvard. Harbage suggested that literary criticism was in need of a word like 'anarchetype' to account for radical innovations in the drama...If Frye had been the debating type, he would have shot back that an archetype has no more politics in it than a metrical form does, and it remains for the individual poet to put a revolutionary or conservative spin on the archetype in question. (Willard, "Archetypes of the Imagination" 21).

Because Frye does not acknowledge the relevance of the collective unconscious to his literary theory, he is missing Jung's theory of the purpose and method of archetypal manifestations, and so he is trapped. Bogdan and his other critics are too compelling to be easily dismissed. If Frye had Jung's ability and desire to explain how it is that mythology has elements that transcend ideology and at the same time acknowledge that all manifestations of mythology are ideologically situated, he might have been more successful with his postmodern critics. However, Frye just gets frustrated and restates his thesis that mythology transcends ideology, and he does not seem to understand why others do not just accept this point. His critics are stating their valid concerns with the archetypal image, and Frye just continues trying to emphasize the archetype itself. He seems to be marginalizing and disregarding the valid concerns raised by the postmodern critic.

Bogdan's book Beyond Communication includes three essays by Bogdan in which she articulates her postmodern feminist critiques of Frye's work. Bogdan, a student and then a colleague of Frye, asked him to write an introduction, which he wrote, but which she then did not publish. In this "Unpublished Introduction to Beyond Communication," which can now be found in Northrop Frye's Writings on Education, Frye wrote,

[W]e have feminist, Marxist or deconstructive critics who are primarily interested in those subjects, and approach literature with the aim of annexing it their main interest. Here every work of literature becomes a document for feminism or Marxism, to be examined within that point of view...Such determinations, it is clear, are imperialistic ideologies out to conquer one more field. Their proponents say that if they didn't conquer it some other ideology would because every critical approach is equally ideological. I think this is a half-truth. An ideology is a myth kidnapped by a power structure or a pressure group, and it is essential to distinguish the ideological from the mythological elements in every work of literature. I wish the present book had 


\section{Dobson}

paid more attention to the study of myths and folk tales and the way in which they reflect the primary concerns of mankind, the concerns of food and sex and property and freedom. Because it is these concerns that the poets have inherited, and just as there is information that is separable from the ideologies that normally transmit it, so there are concerns that belong to all humanity, and are still there whatever their ideological contexts." (612).

Here is the dilemma made manifest in the crucible of a single book and its introduction, which remained unpublished until it was included in Frye's collected works. Frye is trying to separate the manifestations of the archetype, the archetypal images, from the myth, the archetypal pattern, but lacks Jung's language and theory to do so. After the extensive analysis in Bogdan's chapters, Frye responds by merely reiterating the hierarchy between mythology and ideology in a way that does not address her critique. If he had been able to frame his reply in terms of Jungian archetypal theory, he might have seemed more compelling to his critics.

\section{Jung and Postmodern Feminisms}

In using Jung to respond to a postmodern feminist critique of Frye, I think it is germane to consider a postmodern feminist critique of Jung. My project of using Jung to reconcile Frye and his critics is made possible because there are elements of Jung's thought that are modernist and structuralist and there are elements of his thought that are postmodern. Feminist scholar Susan Rowland is not a Jungian analyst and she is certainly not unquestionably supportive of Jung's theories, but in her book Jung: A Feminist Revision, where she critically analyzes Jung from her perspective as a postmodern feminist, she recognizes that

the theory of archetypes as basic, inherited structuring principles within the psyche puts Jung squarely in the tradition of structuralism. Of course, archetypes are not structures in the sense of fixed entities, as they are definitely not inherited images. What archetypes generate in the individual psyche varies widely with cultural, social and personal circumstances. Yet, archetypes are structuralist in suggesting an underlying (if unfathomable) code... [but] the idea... of coexisting separate local truths in the subjectivity of every person aligns Jung with postmodernism. (102-3).

Rowland also considers Jung's work in light of deconstruction and concludes:

On the one hand, the concepts of archetypes and archetypal images are grand theory and logocentric. On the other hand, archetypal images are signifiers without fixed, knowable signifieds. They are subject to skippage and denied logocentric fulfillment. What 
Derrida alleges about language finds a distinct echo in Jung's depiction of psychic imagery. Archetypal images demonstrate differance, differing from each other and infinitely deferring a fixed meaning.

Indeed, given the significance of Jung's unconscious to his psychology as a whole, we could argue, in Derridean language, that his concepts exist 'under erasure'. Theoretical meanings, like any others, cannot be secured, hence the 'erasure' of their claims to fixed truth and authority. In Writing and Difference, Derrida linked Freud to his deconstruction in the radical otherness of the psychoanalytic unconscious, despite the logocentrism present in Freudian writings. I would like to suggest that aspects of Jung's work bear an even more intimate relation to the project of deconstruction. (106).

Neither Rowland nor I are trying to suggest that Jung is a postmodern, Derridean feminist, but we are recognizing that Jung's theories have elements that are similar to and compatible with a postmodern perspective.

Rowland points out, from this complex perspective, which holds the tensions between modernism and postmodernism, that in considering the nature of archetypal theory, "we need to remember that unconscious archetypes are androgynous and plural"(40), Later in the book, she describes Jung's "androgynous archetypes, which are representable only through culturally influenced archetypal images" (84). According to Rowland, Jungian archetypal theory ought to ameliorate the influence of patriarchy because "the Jungian unconscious is a nexus of superior creative powers, not culturally derived. The unconscious should compensate for and combat cultural stereotyping" (42).

Rowland points out how the androgynous and apolitical archetypes are shared but that gendered, political, archetypal images are situated:

By going back to Jung's definition of the archetype, I would suggest there is a structuring of subjectivity that does engage with a feminism interested in a cultural and material shaping of gender identity. The formless archetype supplies creative energy: the resulting image is also shaped by the subject's bodily and social integration into a culture.

For example, methods of mothering have varied enormously across cultures and histories. An archetypal image of 'mother' will partake of this diversity by being formed through a particular subjectivity, culture, society and historical moment. It can be examined as one manifestation of the ineffable multiplicity of the archetype and as witnessing material conditions. (79). 


\section{Dobson}

Here, in discussing an archetypal image of mother as one manifestation of the archetype of mother while at the same time possessing the material conditions of its situatedness, Rowland seems to echo Frye's contention that it is possible to distinguish the myth from the ideology — as seen through my hypothesis that by myth Frye means archetype and that he sees ideology as an archetypal image.

In considering Jung's work in light of the feminist theories of Helene Cixous, Rowland writes,

Cixous has made the greatest impact on feminist theory in what she has called the 'ecriture feminine'. In the first place, the idea of 'feminine writing' is indebted to Derrida in writing as subject to differance. This entails writing as a continual slippage of meaning, the undoing of theoretical claims to secure signifying and to a unitary gendered subjectivity. Ecriture feminine as a deliberate embrace of differance is a writing that undoes patriarchal binary oppositions. It rejoices in spilling meaning. (116).

[T]here are distinct possibilities for such post-Lacanian thinking to draw out feminist potential in the ideas of Jung. As noted, ecriture feminine as differance is close to the 'writing' of archetypal images, which work through difference from each other and infinite deferral of a single logocentric fulfillment of the meaning potential of archetypes." (117).

While Rowland expresses concern and criticism over some aspects of Jungian theory from her location as a postmodern feminist, she regards Jung as a valuable thinker in postmodernism and a potential partner in postmodern feminisms (130). Her optimism regarding Jungian thought derives at least in part due to his subtle formulation of archetypal theory as shared yet situated, political yet apolitical, and androgynous yet gendered.

\section{Polysemous Meaning}

Ideological readings may not separate the archetype from the archetypal image, but they also may not embrace the polysemous nature of the archetypal image itself. Even within the archetypal image, the symbolic nature of art entails that many readings are possible, but an ideological reading can shut down the validity of other interpretations (though it does not have to). No ideology can contain the range of possibilities of human potential, and this is as true of literary interpretation as it is of modes of human behaviour. Art is symbolic and supports many, and often contradictory, ideological interpretations (without suggesting that 'anything goes'); an ideological perspective may not validate other hermeneutic points of view. There is a distinction to be made in the ideological responses to 
which I refer. One kind of response posits, for instance, a Marxist or feminist interpretation of a work and accepts its perspective as one of many possible viewpoints. It would be interesting, for instance, to consider feminist, Marxist and post-colonial, historical, and biographical analyses of the same work. Each perspective would be a lens with which to view the art, each noticing and overlooking different characteristics of the work. However, another ideological stance, and the one with which I take issue, might condemn a work as inherently problematic. The problem here is that if a work is seen to be inherently patriarchal, no other reading can be considered valid. I am also suggesting that Frye's stance accepts the first kind of response but not the second.

Assertions that archetypes are no more political than the structural forms of poetry or music, as seen in Frye's intention to "outline a few of the grammatical rudiments of literary expression, and the elements of it that correspond to such musical elements as tonality, simple and compound rhythm, canonical imitation, and the like" (AC 133), and Willard's claim "that an archetype has no more politics in it than a metrical form does, and it remains for the individual poet to put a revolutionary or conservative spin on the archetype in question" (21) are disputed by feminist critics who argue that the very nature of such forms can themselves be patriarchal, as seen above with Bogdan. Susan McClary makes such a claim in her 1991 publication Feminine Endings: Music, Gender, and Sexuality, in which she asserts that tonality and musical form, such as the sonata, are inherently patriarchal because the structures mirror the male sexual experience: an accelerating rhythm ending in a climax (12-13). She does so while maintaining that her analysis is rooted only in "the music itself" and that therefore her feminist stance has disclosed a patriarchal aspect inherent in the music (23), not that feminisms provide an acceptable interpretation alongside a myriad of other acceptable interpretations. Feminist musicologist Elizabeth Sayrs acknowledges the symbolic nature of art, of even the structure or form of art, when she responds to these assertions by McClary. Sayrs suggests an alternate interpretation of the same tonality and musical forms: the musical structure can be, but is not necessarily or only, seen as a metaphor of the process of childbirth, where accelerating contractions provide a definite climax in childbirth. Here in a flash, the seemingly 'inherently patriarchal' aspects of the musical form are dissipated in an interpretation acceptable to some feminisms.

This work from a feminist author implies that to suggest a structure of art is inherently patriarchal is a problematic assertion as it does not acknowledge the very nature of symbol and metaphor, which are open to many, various and evolving interpretations. If the structure is archetypal, metaphorical, and symbolic, to claim it is inherently patriarchal is reductionist and denies the potential for difference. There may be ideological elements and interpretations of valid concern, elements that need to be defined and analyzed, but because of the metaphorical and symbolic 


\section{Dobson}

nature of art, there are also other, different, and varied interpretations and uses to be made of the literature that tend to be invalidated by an ideological interpretation.

I accept Bogdan's feminist interpretation of "The Painted Door" as valid and important. My point is rather that the polysemous nature of art supports numerous valid perspectives, none of which can claim sole authenticity. I repeat that I do not mean to suggest that any interpretation will be acceptable. I also refer again to my earlier distinction between two kinds of ideological interpretations: one that accepts the polysemous nature of art (accepts a variety of analyses of the archetypal image) and another that, from an ideological perspective, asserts a work of art is inherently problematic (asserts a single 'correct' analysis of the archetypal image).

I suggest that narrative form is no more inherently patriarchal than musical form, and to suggest otherwise is to reify an ideological perspective that does not recognize the polysemous nature of art's structure as well as art's content. Not only is there a conflation of the archetypal image and the archetype, there is also an assertion of a single 'True' interpretation of the polysemous archetypal image. I am not attempting to negate a feminist interpretation of literature in general or this story in particular; I only seek to assert that any ideological perspective goes too far when it states that the form or structure of a work of art is inherently problematic. This perspective refuses to acknowledge the symbolic and metaphoric nature of art. It takes one interpretation of that which is symbolic and declares it to be the 'Truth.' Suggesting a work of literature is inherently patriarchal prevents any other interpretation of the literature, and as I have shown with the sonata form, it therefore restricts interpretations that may in fact even be amenable to ideological critics. This kind of ideological criticism ignores the symbolic nature of art and is a kind of hermeneutic bullying.

So there are two reasons that in the domain of literary studies Frye gives a privileged position to what he calls the myth rather than the ideology: ideology may not acknowledge the symbolic nature of even the archetypal image, and, furthermore, it does not recognize the distinction between the image and the archetype. Frye is not denying the ideological context but rather emphasizing the structure within the manifestation (the archetype), and he is doing so to create a field of literary theory and criticism rather than ideological theory. The distinction between the archetype and the archetypal image in Jungian archetypal theory provides a means of further explicating Frye's project and responding to postmodern criticism. This point is at the crux of postmodern criticism of Frye's literary theory, and I think, has contributed significantly to a marginalized role for archetypal literary studies in the academy as a whole. I am not suggesting Bogdan is the sole voice articulating such criticisms but rather that her presentation of them is an exemplar of a larger trend. In this way, archetypal literary theory has, in fact, 
suffered generally due to its specific and limited implementation by Frye, who acted as its primary and most visible advocate in the academy.

\section{Conclusion}

Archetypal literary theory does not seek to eradicate or ignore the particularities of any literary work (which include its ideologies). In fact, it is in comparing the differences between the particularities of this work and those of previous manifestations of an archetypal image that interest and meaning is found for the archetypal critic. The emphasis is not on the archetype nor on the archetypal image, not on the myth nor on the ideology, but always on the relationship between the two. In The Spirit in Man, Art and Literature, Jung shows that the task of archetypal criticism is in considering the similarities and differences between this archetypal image and previous archetypal images, and in considering the symbolic implications of these affinities and variances.

My hope has not been to denigrate the important advances made in feminist theory, which I support, but rather to illustrate that archetypal theory reminds us that no ideological stance can capture the potential of the human psyche nor contain the symbolic nature of human expression. Frye reminds the reader that "no social vision is ever definitive; there is always more outside it. The circle of stories (or ocean of story, as it is called in India) is there to keep us continually expanding and reshaping that vision" (Frye, "On Teaching Literature," 460). If I have been successful in articulating my hypothesis, this work represents a means of utilizing archetypal literary theories without disregarding valuable contributions of postmodern critical perspectives. I hope therefore, it has contributed somewhat to validating the vital and powerful position of archetypal theory in contemporary literary studies, and, perhaps, throughout the academy.

\section{Works Cited}

Bogdan, Deanne. Re-Educating the Imagination: Towards a Poetics, Politics, and Pedagogy of Literary Engagement. Portsmouth, NH: Boynton-Cook/Heinemann, 1992.

Bogdan, Deanne and Stanley Straw, eds. Beyond Communication: Reading Comprehension and Criticism. Portsmouth, NH: Boynton-Cook/Heinemann, 1990.

Bogdan, Deanne, James E. Cunningham, and Hilary Davis. "Reintegrating Sensibility: Situated Knowledges and Embodied Readers." New Literary History, Vol. 31, No. 3 (2000): 477-507.

Frye, Northrop. Anatomy of Criticism. Princeton, New Jersey: Princeton University Press, 1957.

"Forming Fours." The Hudson Review 4.4 (1958). 611-619.

The Educated Imagination. Toronto, Ontario: House of Anansi Press, Ltd., 1963. 


\section{Dobson}

“The Social Importance of Literature.” Northrop Frye's Writings on Education. CW 7. Eds. Jean O'Grady and Goldwin French. Toronto, Ontario: University of Toronto Press, (1968) 2000 .

-----. The Great Code. Toronto, Ontario: Penguin Books Canada Ltd., 1981.

"Humanities in a New World." Divisions on a Ground: Essays on Canadian Culture. Ed. James Polk, Toronto, Ontario: House of Anansi Press, 1982.

-------. The Critical Path. Brighton, Sussex: Harvester Press, 1983.

"Literature as a Critique of Pure Reason.” Descant 14.2 (1983). 7-21.

Fables of Identity. San Diego: Harcourt Brace Jovanovich, 1986.

"Motive for Metaphor.” Modern Canadian Essays. Toronto, Ontario: Macmillan of Canada, 1976.

------. Creation and Recreation. Toronto, Ontario: University of Toronto Press, 1980

Words with Power. Toronto, Ontario: Penguin Books Canada Ltd., 1990.

“Literature as Therapy.” The Eternal Act of Creation, Essays 1979-1990. Ed. Robert Denham. Indiana, Illinois: Indiana University Press, (1989) 1993.

“On Teaching Literature.” Northrop Frye's Writing on Education CW 7 Eds. Jean Grady and Goldwin French. Toronto, Ontario: University of Toronto Press, 2000.

-----. Northrop Frye's Late Notebooks, 1982-1991: Architecture of the Spiritual World, Vols. 5 and 6. Ed. Robert Denham. Toronto, Ontario: University of Toronto Press, 2000.

Jung, Carl. Archetypes of the Collective Unconscious. London, UK: Routledge \& Kegan Paul, 1959.

------. Memories, Dreams, Reflections. New York: Vintage Books, 1961.

------. Man and His Symbols. New York: Dell Publishing, 1964.

------. "Psychology and Literature." The Spirit in Man, Art, and Literature. Princeton, USA: Princeton University Press, 1966.

------. "On the Relation Between Analytical Psychology and Poetry." The Spirit in Man, Art, and Literature. Princeton, USA: Princeton University Press, 1966.

------. The Spirit in Man, Art, and Literature. Princeton, USA: Princeton University Press., 1966.

-------. Four Archetypes. Princeton, USA. Princeton University Press, 1970 (1992).

-------. Psychology and Alchemy. London: Routledge \& K. Paul, 1974.

------. On the Nature of the Psyche. Princeton, USA: Princeton University Press, 1960 (1970).

Krysinski, Wladimir. "Frye and the Problems of Modernity." The Legacy of Northrop Frye. Eds. Alvin A. Lee and Robert Denham. Toronto, Ontario: University of Toronto Press, 1994. 
McClary, Susan. Feminine Endings: Music, Gender, and Sexuality. Minneapolis: University of Minnesota Press, 1991.

Rowland, Susan. Jung: A Feminist Revision. Cambridge, UK: Polity Press/Blackwell Publishers, Ltd., 2002.

Salusinsky, Imre. "Frye and Ideology." The Legacy of Northrop Frye. Eds. Alvin A. Lee and Robert Denham. Toronto, Ontario: University of Toronto Press, 1994.

Sayrs, Elizabeth. "Deconstructing McClary: Narrative, Feminine Sexuality, and Feminism in Susan McClary’s Feminine Endings.” College Music Symposium, 33-34, 1993-1994.

White, Hayden. "Frye's Place in Contemporary Cultural Studies." The Legacy of Northrop Frye. Eds. Alvin A. Lee and Robert Denham. Toronto, Ontario: University of Toronto Press, 1994.

Willard, Thomas. “Archetypes of the Imagination.” The Legacy of Northrop Frye. Eds. Alvin A. Lee and Robert Denham. Toronto, Ontario: University of Toronto Press, 1994.

\section{Abbreviations}

$\begin{array}{ll}\text { AC } & \text { Anatomy of Criticism } \\ \text { WP } & \text { Words with Power } \\ \text { FA } & \text { Four Archetypes } \\ \text { OTNOTP } & \text { On the Nature of the Psyche }\end{array}$

